\title{
Pengembangan lembar kerja siswa materi garis singgung lingkaran untuk pembelajaran menggunakan model inquiry
}

\author{
Baharudin Kristian Parinata, Sri Mulyati* \\ Universitas Negeri Malang, Jl. Semarang No. 5 Malang, Jawa Timur, Indonesia \\ *Penulis korespondensi, Surel: sri.mulyati.fmipa@um.ac.id
}

Paper received: 01-11-2021; revised: 15-11-2021; accepted: 30-11-2021

\begin{abstract}
Based on observations at PPL in SMP 21 Malang in 2012/2013, many student of class $8^{\wedge}$ th and $9^{\wedge}$ th are forget how to calculate the length of common tangent. The purpose of this development is to produce a student worksheet on the material tangent for activity learning using Inquiry model which is valid, practical, and effective.Development of student worksheet on tangen material for activity learning using Inquiry models was adapting by Plomp model. In developing a learning media consists of five phases: (1) initial investigation phase, (2) the design phase, (3) phase of realization / construction, (4) phase of the test, evaluation, and revision (5) the implementation phase. According from validation and the results of field trial the student worksheets were developed was valid by percentage of 88.3 percent, practically by percentage of 87.5 percent, and called effective because the scores that were obtained by six students in to answer evaluation had passed the minimum passing score which is given is 75 .
\end{abstract}

Keywords: student worksheets; inquiry model; tangen.

\begin{abstract}
Abstrak
Berdasarkan observasi saat PPL di SMP Negeri 21 Malang tahun 2012/2013, banyak siswa kelas VIII dan IX lupa saat ditanya bagaimana cara menghitung panjang garis singgung persekutuan dua lingkaran. Tujuan dari pengembangan ini untuk mengembangkan lembar kerja siswa dengan materi garis singgung lingkaran untuk pembelajaran menggunakan model Inquiry yang valid, praktis dan efektif. Pengembangan lembar kerja siswa materi garis singgung lingkaran untuk pembelajaran model Inquiry ini dikembangkan dengan mengadaptasi model Plomp. Dalam mengembangkan media pembelajaran terdiri menjadi lima fase yaitu : (1) fase investigasi awal, (2) fase desain, (3) fase realisasi/konstruksi, (4) fase tes, evaluasi, dan revisi (5) fase implementasi. Berdasarkan hasil validasi dan uji coba lapangan lembar kerja siswa yang dikembangkan valid dengan persentase 88,3 persen, praktis dengan persentase 87,5 persen, dan dikatakan valid karena nilai evaluasi yang didapatkan oleh enam siswa memenuhi kriteria kelulusan minimal yang diberikan yaitu 75
\end{abstract}

Kata kunci: lembar kerja siswa; model inquiry; garis singgung lingkaran.

\section{Pendahuluan}

Berdasarkan observasi saat PPL di SMP Negeri 21 Malang tahun 2012/2013, banyak siswa kelas VIII dan IX lupa saat ditanya bagaimana cara menghitung panjang garis singgung persekutuan dua lingkaran. Hal tersebut terjadi karena siswa hanya menghafal rumus atau sifat dari garis singgung lingkaran tanpa mengetahui dari mana asalnya.

Sebenarnya menghitung panjang garis persekutuan dua lingkaran adalah penerapan dari Teorema Phytagoras. Karena itu perlu dirancang suatu media pembelajaran tentang garis singgung lingkaran yang melibatkan siswa aktif untuk mengkonstruksi sendiri apa itu garis singgung lingkaran dan bagaimana cara menghitung panjang garis singgung persekutuan dua lingkaran. 
Salah satu media yang digunakan dalam proses pembelajaran adalah Lembar Kerja Siswa (LKS). Lembar kerja siswa (LKS) merupakan salah satu media yang tepat bagi peserta didik karena LKS membantu peserta didik untuk menambah informasi tentang konsep yang dipelajari melalui kegiatan belajar secara sistematis.

Model Inquiry adalah model yang menekankan pada proses pengolahan informasi pada peserta didik sehingga memudahkan siswa dalam memahami suatu materi. Oleh karena itu, tujuan dari pengembangan ini adalah menghasilkan lembar kerja siswa pada materi garis singgung lingkaran menggunakan model Inquiry yang valid, praktis, dan efektif. Langkahlangkah model Inquiry meliputi: Langkah-langkah yang ditempuh dalam penggunaan model Inquiry menurut Sanjaya (2006: 201), sebagai berikut:

1. Orientasi siswa pada masalah

Guru mengajak siswa merumuskan tujuan pembelajaran, menuliskan logistik yang dibutuhkan dan memotivasi siswa terlibat pada aktivitas pemecahan masalah yang diberikan.

2. Merumuskan Masalah

Kegiatan Inquiry dimulai ketika pertanyaan atau permasalahan diajukan. Masalah yang dikaji adalah masalah yang mengandung teka-teki yang jawabannya pasti. Siswa akan dituntun untuk mencari dan mendapatkan jawaban dari permasalahan yang diberikan, kemudian siswa diminta untuk merumuskan hipotesis.

3. Merumuskan Hipotesis

Hipotesis adalah jawaban sementara atas pertanyaan atau solusi permasalahan yang dapat diuji dengan data. Untuk memudahkan proses ini, guru menanyakan kepada siswa gagasan mengenai hipotesis yang mungkin.

4. Mengumpulkan Data.

Mengumpulkan data adalah aktifitas siswa menjaring informasi yang dibutuhkan untuk menguji hipotesis yang diajukan. Peran guru dalam tahap ini adalah memberikan pertanyaan yang dapat memeberikan petunjuk bagi siswa untuk mencari informasi yang diperlukan.

5. Menguji Hipotesis

Menguji Hipotesis adalah proses menetukan jawaban yang dianggap diterima sesuai dengan data atau informasi yang diperoleh berdasarkan pengumpulan data. Yang terpenting dalam menguji hipotesis adalah tingkat keyakinan siswa atas jawaban yang diberikan berdasarkan data yang ditemukan siswa.

6. Merumuskan Kesimpulan

Langkah penutup dari pembelajaran Inquiry adalah membuat kesimpulan berdasarkan data yang diperoleh siswa. Pembelajaran akan lebih bermakna jika siswa diberi kesempatan untuk tahu dan terlibat secara aktif dalam menemukan konsep dari faktafakta yang didapat dengan bimbingan guru. 


\section{Metode}

Model

Pengembangan lembar kerja siswa materi garis singgung lingkaran untuk pembelajaran menggunakan model Inquiry ini dikembangkan dengan mengadaptasi model Plomp. Dalam mengembangkan media pembelajaran terdiri menjadi lima fase yaitu :

1) Fase investigasi awal

Kegiatan yang dilakukan pada fase ini terfokus pada pengumpulan dan analisis informasi, merumuskan masalah dan merencanakan kegiatan selanjutnya.

2) Fase desain

Fase ini difokuskan kepada hasil yang telah didapat dari fase investigasi awal.. Kegiatan dalam fase ini meliputi pemilihan media dan materi.

3) Fase realisasi/konstruksi

Fase ini merupakan fase produksi media yang dikembangkan dalam hal ini adalah lembar kerja siswa. Kegiatan yang dilakukan pada fase ini adalah menyusun sintaks dan memberikan gambaran umum tentang LKS yang dikembangkan.

4) Fase tes, evaluasi, dan revisi

Fase evaluasi akan menentukan apakah produk yang dikembangkan telah sesuai standart atau tidak. Kegiatan yang dilakukan pada fase ini terdiri dari dua kegiatan utama yaitu validasi dan uji coba.

5) Fase implementasi.

Fase ini merupakan solusi yang dihasilkan pada tahap evaluasi. Dengan demikian, desain solusi dapat diimplementasikan dalam situasi pembelajaran. Tahap implementasi ini dibagi menjadi dua yaitu : analisis data hasil validasi dan hasil dari uji coba kelompok kecil.

\section{Uji Coba Produk}

Uji produk dilakukan untuk memperoleh data yang dapat digunakan sebagai dasar untuk menetapkan tingkat kevalidan, kepraktisan, serta keefektifan produk. Selain itu, untuk menghasilkan produk yang dapat digunakan oleh siswa SMP. Uji coba produk dilakukan dengan melakukan uji kevalidan produk pengembangan yang divalidasi oleh pakar matematika, yaitu dosen matematika dan guru matematika SMP. Kemudian uji coba kepraktisan dan keefektivan dilakukan oleh siswa 6 siswa SMP kelas VIII.

Tingkat kevalidan produk pengembangan diukur dengan penilaian validator dari lembar validasi. Data yang diperoleh, dianalisis menggunakan teknik analisis sebagai berikut : 


$$
P=\frac{\sum \bar{V}_{i}}{\sum V_{i}}
$$

Keterangan :

$\mathrm{P}=$ menyatakan prosentase nilai

$\bar{V}_{i}=$ menyatakan total rata-rata skor item dari semua validator

$V_{i}=$ skor maksimum dari semua item

Sedangkan sebagai dasar pengambilan keputusan untuk merivisi produk digunakan kriteria penilaian yang diadaptasi dari buku Dasar-Dasar Evaluasi Pendidikan oleh Arikunto.

\section{Kriteria Kevalidan Produk Pengembangan}

\begin{tabular}{|l|l|l|}
\hline Skala & Kriteria Validitas & Keterangan \\
\hline $85-100$ & Sangat valid & Tidak Revisi \\
\hline $70-84$ & Valid & Tidak Revisi \\
\hline $55-69$ & Cukup valid & Tidak Revisi \\
\hline $50-54$ & Kurang valid & Revisi \\
\hline $0-49$ & Tidak valid & Revisi \\
\hline
\end{tabular}

(Diadaptasi Arikunto, 2009 : 245)

Selain kevalidan, uji coba produk ini juga dengan melakukan uji kepraktisan. Kepraktisan lembar kerja siswa diukur dengan penilaian angket yang diisi oleh siswa. Data yang diperoleh, dianalisis menggunakan teknik analisis sebagai berikut :

$$
P=\frac{\sum_{i=1}^{n} x_{i}}{n k} \times 100 \%
$$

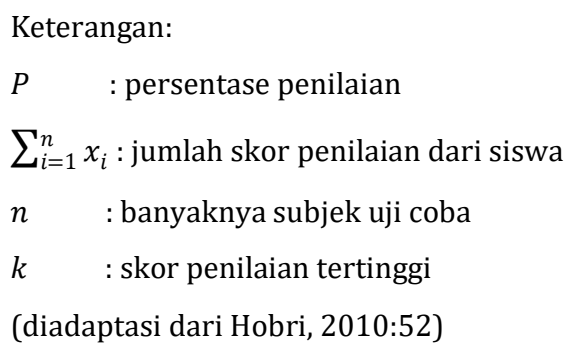

Sedangkan sebagai dasar pengambilan keputusan untuk merivisi produk digunakan kriteria penilaian yang diadaptasi dari buku Dasar-Dasar Evaluasi Pendidikan oleh Arikunto.

\section{Kriteria Kepraktisan Produk Pengembangan}

\begin{tabular}{|l|l|l|}
\hline Skala & Kriteria Kepraktisan & Keterangan \\
\hline $85-100$ & Sangat praktis & Tidak Revisi \\
\hline $70-84$ & Praktis & Tidak Revisi \\
\hline $55-69$ & Cukup Praktis & Tidak Revisi \\
\hline $50-54$ & Kurang praktis & Revisi \\
\hline $0-49$ & Tidak praktis & Revisi \\
\hline
\end{tabular}

(Diadaptasi Arikunto, 2009 : 245) 
Uji coba keefektifan produk hasil pengembangan dilakukan kepada siswa kelas VII SMP. Hal ini bertujuan untuk mengukur tingkat keberhasilan produk pengembangan lembar kerja siswa yang telah dikembangkan. Untuk mengukur tingkat keefektifan produk pengembangan dilihat dari nilai soal evaluasi yang dikerjakan oleh siswa. Apabila semua nilai siswa memenuhi kriteria ketuntasan minimal yang ditentukan yaitu 75 maka lembar kerja siswa yang dikembangkan dikatakan efektif.

\section{Hasil dan Pembahasan}

Berdasarkan hasil validasi dan uji coba lapangan terhadapa lembar kerja siswa didapatkan hasil sebagai berikut:

1. Uji kevalidan

Berdasarkan hasil analisis data hasil penilaian lembar validasi oleh validator yaitu dosen matematika dan guru SMP diperoleh lembar kerja siswa yang telah dikembangkan memenuhi kriteria sangat valid dengan persentase $88,3 \%$

\section{Uji Kepraktisan}

Dari analisis data angket siswa yang dilakukan oleh 6 siswa uji coba, diperoleh lembar kerja siswa yang telah dikembangkan dikatakan praktis dengan persentase 83,7\%.

3. Uji keefektifan

Dari analisis data nilai evaluasi 6 siswa uji coba, diperoleh lembar kerja siswa yang telah dikembangkan dikatakan efektif karena nilai yang didapat oleh semua siswa memenuhi kriteria kekulusan minimal yaitu 75 .

Berdasarkan analisis data hasil uji coba kevalidan, kepraktisan, dan keefektifan yang telah diuraikan di atas, dapat disimpulkan bahwa produk lembar kerja siswa dapat digunakan untuk siswa jenjang SMP dalam pembelajaran matematika dengan materi garis singgung lingkaran.

\section{Simpulan}

Berdasarkan uji coba dapat disimpulkan LKS yang dikembangkan dikatakan valid dengan persentase $88,3 \%$. Sementara itu berdasarkan hasil uji coba dapat disimpulkan bahwa LKS yang dikembangkan dikatakan praktis dengan persentase $87,5 \%$. LKS yang dikembangkan dikatakan efektif karena keenam siswa mendapatkan nilai lebih dari 75 saat mengerjakan soal evaluasi. Karena memenuhi tiga kriteria yaitu valid, praktis dan efektif, maka LKS yang dikembangkan layak digunakan sebagai alternatif bahan ajar matematika pada pokok bahasan aturan garis singgung lingkaran.

Adapun saran pengembangan lembar kerja siswa lebih lanjut adalah sebagai berikut :

1. Pengembangkan LKS ini hanya terbatas pada pokok bahasan garis singgung lingkaran. Oleh karena itu, diharapkan ada tindak lanjut pengembangan LKS dengan model Inquiry untuk pokok bahasan lainnya. 
2. Bagi pengembang yang lain, disarankan untuk menambahkan bagaimana cara menggambar garis singgung lingkaran dan garis singgung persekutuan dua lingkaran secara matematis.

3. Bagi pengembang lain, disarankan untuk mengujicobakan pada kelompok sedang maupun besar agar dapat diketahui tingkat keefektifannya.

4. Bagi guru dapat mengembangkan LKS ini sesuai dengan kondisi siswa dan sekolah yang bersangkutan.

\section{Daftar Rujukan}

Arikunto, Suharsimi. (2009). Dasar-dasar evaluasi pendidikan. Jakarta: Bumi Aksara.

Depdiknas. (2008). Pengembangan bahan ajar. Direktorat Pembinaan Sekolah Menengah Atas Direktorat Jenderal Manajemen Pendidikan Dasar dan Menengah Departemen Pendidikan Nasional.

Ibrahim, R \& Syaodin, Nur. (2003). Perencanaan pengajaran. Jakarta : PT Rineka Cipta.

Mulyati, S. (2000). Geometri euclid. Malang: JICA.

Musser dkk. (2010). College geometry : a problem solving approach with application. Canada: Pearson.

Nasional, D. P. (2006). Kurikulum tingkat satuan pendidikan; standar kompetensi matematika SMP/MTs.

Nasional, K. P. (2010). Universitas Negeri Malang. Pedoman penulisan karya ilmiah. Edisi ke lima.

Principles, N. C. T. M. (2000). Standard for school mathematics. Resto, Virginia: The National Council of Teachers of Mathematics.

Sanjaya, Wina. (2006). Pembelajaran berorientasi standar proses pendidikan. Jakarta : Media Grafika 77.

Sugiyono, M. P. P. P. K. (2007). Kualitataif dan r\&d, Bandung: Alfabeta, 2010. Sugiyono, Metode Penelitian Kuantitatif kualitatif dan R\&D Bandung: Alfabeta.

Syaiful, S. (2013). Konsep dan makna pembelajaran untuk membantu memecahkan problematika belajar dan mengajar. Bandung: Alfabeta.

Trisnawati, Rina. (2012, April 28). LKS (Worksheet). http://reenha-trisnawati.blogspot.com/2012/04/blogpost.html

Yamin, M., \& Ansari, B. I. (2008). Taktik mengembangkan kemampuan individual siswa. Jakarta: Gaung persada pers. 